\title{
The Geography of Power in South America: Divergent Patterns of Domination in Spanish and Portuguese Colonies
}

\author{
KENNETH N. CLARK, ELISA DEL BONO, and ANTONIO LUNA GARCIA \\ University of Arizona \\ USA
}

\begin{abstract}
The authors of this paper explore the geography of power in South America as expressed by Spain and Portugal in their different patterns of development in colonial America. The paper outlines the political position of each country during the Age of Discovery, the political attitudes of each and the resultant urban morphologies and spatial organizations developed by each colonial power. A close examination of two South American colonial cities-one Spanish, one Portuguese-reveals that the Spanish urban pattern promoted a hierarchy of interconnected cities of gridded layout, with key state and religious functions strategically located in relationship to the plaza. Portugal, in contrast, created a series of isolated commercial-military towns, of informal morphology with key state and religious functions distributed according to topography. Two case studies of Spanish and Portuguese colonial cities clearly illustrate the divergent policies and patterns of spatial control of these two important colonizing powers of the fifteenth and sixteenth centuries.
\end{abstract}

\section{INTRODUCTION}

The Spanish decision to sponsor a trans-Atlantic route, its subsequent encounter and domination in the New World has long been the subject of scholarly study on both sides of the Atlantic, particularly in conjunction with the Quincentenary of 1992. ( C.E.H.O.P.U. 1989; Hardoy, 1991). In contrast, the Portuguese decision to discover a southerly route around Africa and the subsequent experience in the Americas has not been as thoroughly studied and rarely compared to the Spanish experience.

The American territory was first divided between Spain and Portugal by the treaty of Tordesillas, which in 1494 created the official division of the western hemisphere. The spatial power expression of the these two different colonial empires can be studied through the analysis of the urban patterns and the structuring of the territory by both Iberian countries. In the 15 th century, both Spain and Portugal were Christian countries which had recently overthrown centuries of Moslem domination. However, they were also in two different socio-economic and historical situations.

\section{IBERIAN POWERS AT THE END OF THE 15TH CENTURY}

At the time of the discovery, the Iberian peninsula was divided among three different political powers: Aragon, Castile, and Portugal. However, Castile and Aragon had been united by the marriage of King Ferdinand (Aragon) and Isabella (Castile) forming the basis for a united Spain. In spite of the royal marriage, both kingdoms maintained their political independence.

The conquest of Granada in 1492 by the Castilian Army, marked the end of a long period of military struggle and spatial expansion that started almost seven centuries before. Castile used its well developed military power for spatial expansion and domination in the Iberian peninsula.

Portugal, as well as Aragon, terminated the Moslem domination relatively early and started to compete for the domination of the new international trade with the far East. Aragon - with cities like Barcelona - tried to dominate the western Mediterranean trade traffic, competing with cities like Genoa, Naples and even Venice. On the other hand, Portugal--under the leadership and influence of the royal house of Aviz founded by King Juan I (1385-1433) became the most influential commercial power in Europe. The 15th century marked the expansion of its commercial routes around Africa to reach the Far East ( Hardoy, 1991). During the 16th century, Lisbon was not only the capital of the kingdom and principal residency of the royal family but also a commercial center of French, Genoese, Venetian, Flemish, English and Scandinavian interest. Lisbon was also the principal center of cartographic production and the main center of the naval expertise in the world.

The discovery of America by Christopher Columbuswhich occurred almost simultaneously with the conquest of Granada--was a symbol of the new interest by Castile to start to compete with the other Iberian kingdoms for commercial routes in the Atlantic (Soria, 1991). The conquest of America also marked the end of the supremacy of the Mediterranean as the primary center of world economic activity. The Atlantic ocean became the new focus of international economic activity, for both trade with the 
Americas as well as the Far East (Berry, 1987). This economic shift contributed to the decline of Aragon (and other Mediterranean city-states) as a major commercial power, leaving the leadership in the economic and political arena to its new partner Castile.

\section{SPAIN AND PORTUGAL: DIFFERENT PATTERNS OF SPATIAL ORGANIZATION}

The organization of the colonial territories in America reflects both the economic and political differences of Spain and Portugal. The geography of power can be seen both at the regional scale and at the local (urban) scale. Colonial cities were instruments of domination and acculturation used by both colonial empires. Portuguese and Spanish colonial cities in America can be seen as the structural representations of the complex web of social, political and economic relations between the mother country and the colony and between the city and the countryside.

\section{The Spanish colonial model}

The early Spanish colonial period initiated the simultaneous process of conquest and colonization. The conquest assured the ownership of the land, while the colonization encouraged penetration and the creation of new settlements for colonists and their institutions. (Martin and Múscar, 1992). Cities had a powerful role in this dual process. Kubler (Kubler 1986) using a theory by Richard Morse writes that the colonial American cities had a centrifugal effect on the domination of new territories. Newly established colonial cities formed centers from which new settlers were sent to colonize the surrounding territories.

The cities were based on a legal-theological ideology. The network of new cities had the effect of creating a dependent world on the periphery of the metropolis (Martin and Múescar, 1992). Spanish colonial cities were founded to preserve and extend western Christian civilization. They were a spatial representation of the ideal Christian moral and social order which contrasted with the immoral and chaotic city layouts of people outside the Christian faith (ie., Moslems and Indians).

Spanish colonial cities can be seen as the nodes of Imperial presence within the territorial structure of Spanish America. Colonial cities had three main functions: administration, commerce and evangelization. Administration was the political element that linked a colonial city to Madrid, along a hierarchical network of colonial cities. At the commercial level, the cities functioned as regional markets where goods and services were exchanged in the local economy. Another function of the colonial city was to spread the Christian faith. The church (or cathedral) was an important element in the diffusion of this aspect of Imperial power. All functions tended to be concentrated in the core of the Spanish colonial town around the plaza. The administrative, economic and religious powers at the regional and Imperial levels were situated on the plaza or in close proximity to it.
Spanish colonial cities were the instruments by which the royal treasury was protected, the power and authority of the king was represented and the Empire was defended. The objective of the Spanish conquistadores was to provide the infrastructure and services at minimum cost through a monopolistic system of institutions. Vives (Vives, 1986) points out some of the effects of this spatial structuring of the Spanish colonial territory. These are:

- bureaucratic concentration of urban planning decisions, - monopolistic model of urban services,

- creation of urban spaces for security and control reasons

The model of urban colonization of the Americas was an extrapolation of the same system the Christian soldiers used for the reconquest of the Iberian territories from the Moslems. The Crown of Castile imposed a formal organization to control newly conquered lands. Cities, the major instruments of dominance, were created to establish administrative and military outposts that could stop eventual incursions by enemies of the Crown. This model of colonization also had an important economic purpose. Castilian royalty practiced the tradition of awarding land in exchange for services of their numerous armies. This practice, common in the Roman empire, was readopted and expanded by the Spanish in the Americas. A country of peasants and ranchers, Castile was relatively weak in commercial activities at the end of the 15th century. Thus the crown had no other resources to pay back the services of its soldiers than with newly conquered lands.

\section{The Portuguese colonial model}

From the beginning, the Portuguese policy of territorial occupation in America was very different from its Spanish counterpart. Indeed, the 16th century Portuguese model of colonization better illustrates an expansionist model of the commercial powers of the late medieval period.

At first, the Portuguese kingdom underestimated the possibilities of Brazil; indeed, during the first half of the 16 th century the Portuguese crown considered the discovery of Brazil a matter of secondary importance. Later, Portugal wanted to consolidate the coast of Brazil (between Santos and Recife) in order to prevent other foreign powers from establishing commercial outposts for the trade of palo brasil. In doing so, Portugal was seeking a monopoly on this new export commodity, that was used in the manufacture of wool in England and in the Low Countries. (Gasparini, 1972)

The first Portuguese settlements in America, like their other settlements on the coast of Africa or in India, were intended to serve for the exchange of goods. They were not established with the same sense of permanence associated with an intention to colonize. Hardoy states that these commercial-military towns were the only type found in Brazil until 1530 (Hardoy, 1978). Other authors (Martin and Múscar, 1992) present the idea that these commercial towns were the only tradition Portugal had at the time of the discovery.

Most of the early Portuguese trading posts established in 
the 16th century were abandoned; only Cabo Frio and Iguaraçu maintained continuity as colonial cities. These early trading posts were simple settlements (ports) for shipping palo brasil which was brought from the hinterland by natives. These initial outposts were followed by a division of the land according to the medieval tradition of capitanias. Thus, the coast was divided into 15 large tracts of land (capitanias) - each extending to the interior of the country. This pattern of land division was not meant for colonization of the interior; rather, it reflects the first port centers which were established to support the 16th century capitanias (Gutierrez, 1992).

The capitanias evolved into semi-independent states without any relationship between themselves. Each belonged directly to the mother country. The capitanias formed the basis for the plantation system which left a characteristic imprint of spatial occupation in colonial Brazil.

Gasparini (Gasparini, 1972) also points to other relevant reasons for the development of a divergent pattern of occupation of the Brazilian territories. These were:

- The Portuguese Imperial System was less systematic and rigid than its Spanish counterpart;

- Their commercial policy was more flexible and open than the Spanish. Portugal allow more penetration from the exterior commerce in its Brazilian colonies. Spain allowed none.

- The Portuguese social stratification was relatively more informal and less systematic and legal. This was reflected by a higher tolerance of foreign immigration and especially of non-Christians to the colonies.

- The Church was relatively less powerful; the religious and evangelizing motivation had a less important role in the Portuguese colonies in America.

\section{BUENOS AIRES, ARGENTINA AND \\ SALVADOR DE BAHIA, BRAZIL:}

Two divergent expressions of the geography of power

Distinct differences between the two colonial powers in America was reflected in their urban morphology. The two cases presented in this study illustrate two particular examples of models of colonization of Spain and Portugal. Buenos Aires and Salvador both became capital cities of their respective colonial administrations. Both were founded on the Atlantic coastline during the mid-16th century. Their physical layouts present good examples of the Spanish and Portuguese colonial urbanism in America during the 16th and 17 th centuries.

\section{Buenos Aires, Argentina}

The section of South America comprising Argentina, Uruguay, and Paraguay takes its name from the Rio de la Plata. The conquest of this section of the New World by Spain was a slow and arduous process, much like that of the English settlements in the United States (Crow, 1980).

In 1536, Don Pedro de Mendoza -a nobleman at the
Spanish court- first founded Buenos Aires, on the southern bank of the Rio Plata. However, the newly founded city was destroyed by Indian attacks and was refounded by Juan de Garay in 1580. As a city near the coast, Buenos Aires followed the classical model of Spanish colonial cities facing the sea, with a main plaza placed almost upon the banks of the river.

The foundational plan of the city of Buenos Aires is what Hardoy (Hardoy, 1991) calls a classical model of a foundational plan-planos fundacionales, - a common practice for Spanish colonial cities founded after 1560 . The foundational plan is a graphic representation of a projected city done by conquistadores or their captains to solicit Royal approval for construction of the city.

These plans show:

1. a checkerboard grid formed by a latticework of parallel and perpendicular which defined regular development blocks;

2. a main plaza or Plaza de Armas formed by an unconstructed development block-usually centralized-except in the case of a coastal city;

3. the distribution of the sites around the plaza or Plaza de Armas to be occupied by the cabildo (city hall), the main church and the Governor's house. Also, the sites for the religious orders and hospitals were designated in different points of the city.

The 1583 de Garay plan for Buenos Aires shows the location of the fort and blocks allocated for the main plaza, the convents of San Francisco, Santo Domingo and Santa Ursula; and for the hospitals. In addition, the plan indicates sites for the cabildo, the jail and the main church. Originally, the city included 135 blocks. Among them, the 35 blocks closest to the main plaza were divided in 4 parts, 7 were divided into two parts and 4 into three. Ten whole blocks and several parts of blocks partially adjudicated were left without ownership.

The most important element in the Spanish colonial urban model was the plaza. Study of this morphological unit has been from two divergent perspectives. Its physical elements have been extensively studied by architects and urban planners. On the other hand, anthropologists, historians and sociologists have studied the importance of the plaza as a social center. One of the singularities of the plaza mayor is the concentration of public buildings. The church, the city hall and commercial activities are located in this central urban space. Solano (Solano, 1985) points out that the concentration of power in such a small area is something innovative. For other authors (Vives, 1986) the plaza was the nexus between the two major urban networks: the imperial and the regional.

The plaza is the central element from which the rest of the city grew.

The Spanish American city could thus grow indefinitely through expansion of the traza or layout while maintaining a near-total stability at the center. The 


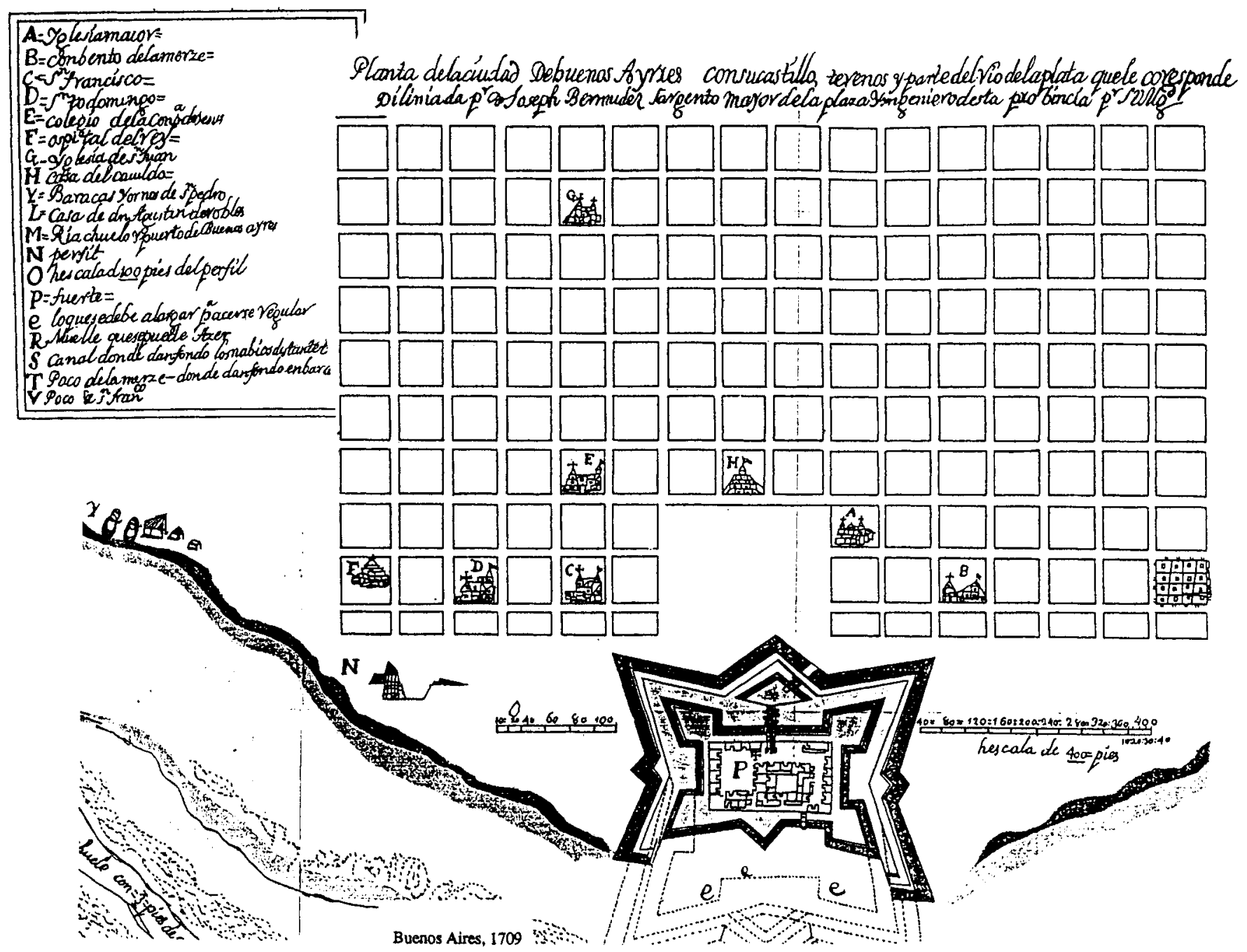

Figure 1. Plan of Buenos Aires in 1709. Author: Buenos Aires, Documentos y Planos Relativos al Periodo Edilicio Colonial de la Ciudad de Buenos Aires, Buenos Aires: J. Peuser, 1910.

overall structure would not vary or need to vary over many centuries: always nucleated, always with a better-developed center and a more provisional edge. (Lockhart \& Schwartz, 1983).

\section{Salvador de Bahia, Brazil}

San Salvador de Bahia was founded in the 16 th century to install a new centralized structure in the Portuguese territories of Brazil, after the failure of the early system of capitanias. In the latter half of the 16th century, the Portuguese crown decided to control the exploitation of the Brazilian resources. For this reason, in 1549 the king of Portugal appointed Tomé de Souza as the first Governor of the entire Brazilian territory. De Souza selected Bahia de Todos los Santos as the best natural defensive harbor on the Atlantic coast to serve as the new capital. Hardoy (Hardoy, 1991) writes that the foundation of these later cities followed formal royal directives, still less rigorous than the Spanish ordinances.
The layout of the cities in Brazil followed the Portuguese urban tradition. Some of the Brazilian cities can be considered replicas of cities in the mother country. Portuguese cities were developed in two distinct parts: ciudade baixa or the lower city-with all the installations related to harbor and commercial activities-and ciudade alta or the upper city - which contained the residential, religious and administrative activities.

Salvador de Bahia and Rio de Janeiro - both capitals during the colonial times which followed this pattern-are the American versions of Lisbon and Oporto.

Portuguese colonial cities in Brazil as well as in Africa and India, were built on high ground near a harbor in the manner of the mother country. Topography played a crucial role in the actual urban layout which had to recognize the rough terrain. Portuguese ordinances allowed a high degree of freedom in urban form. The prescriptions for urban layout were limited to the location of functions and general zoning of the city. Therefore, physical response varied according to 


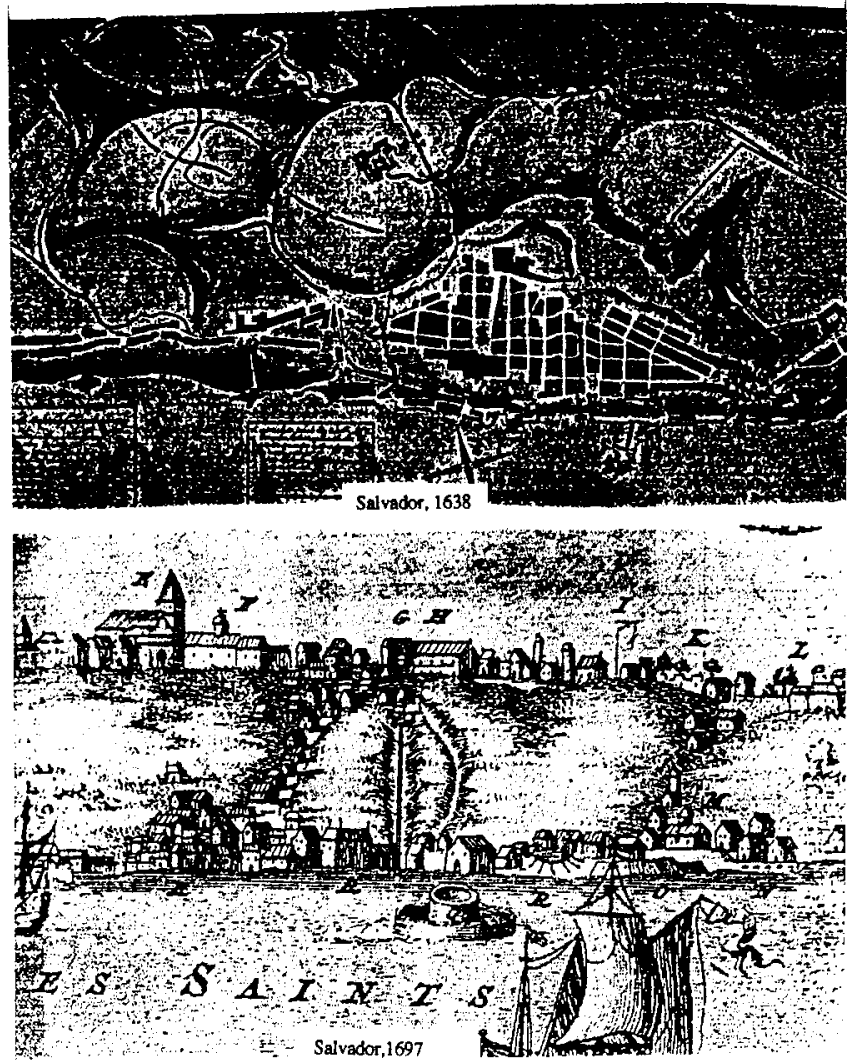

Figure 2. Plan and View of Salvador, 17 th century. From Hardoy, 1991.

topography, with different functions in different areas of the colonial city according to conditions imposed by the site.

Although the checkerboard layout was not prescribed for Portuguese colonial cities, there was an order in Salvadoran informal grid comprised of four streets parallel to the coast crossed by three transversal streets - which formed the core of the city. This same freedom of layout can be seen in the distribution of plazas and streets, which formed secondary cores. Thus, the Portuguese colonial urban structure was closely related to the organic medieval patterns with small squares: abras, compases, and streets of diverse dimension. Brazilian cities show an urban organization which was adapted to the characteristics of their settings. This is reflected in the rectilinear layout of the streets in Salvador. According to Smith (Smith, 1955), the irregular layout of the Portuguese cities in Brazil has been over emphasized as characteristic of the Portuguese colonial city in America and elsewhere.

The three most important morphologic elements of Portuguese colonial towns are the rossio, the terreiro, and the largo. The Portuguese square was the rossio, an open communal piece of land. Its location could vary in relation to the needs of the town, appearing centrally located in some cases and excentric in others. Although they did not have the scale of the larger Hispanic plazas, Brazilian rossios were a well-defined urban open space. The terreiro on the other hand was an undefined open space more related to the activities of the lower town. Finally, the largo was a broad street with commercial functions that included the market.

These three urban features appear in Portuguese cities like Lisbon, Oporto, Bragança as well as smaller towns in the mother country. In the case of 16 th century Lisbon, the rossio was represented by the Praça do Rossio, and the largo by the rua Nova dos Mercaderes. An undefined broad open space north of the city was the site of the market, executions and autos de fe. Terreiros can be found in the Terreiro do Poço and Terreiro do Paço de Riveira, which both opened towards the Tajo River. These were undefined open spaces used for the disembarking of ships and venues of arsenal warehouses related to activities of the port.

\section{FINAL REMARKS}

During the early centuries of colonization of the Americas, Spain and Portugal had several commonalties: each was searching for a water-borne route to India and the Far East, both occupied the Iberian peninsula which became a strategic location for naval explorations to the south and west, each had experienced Moslem occupation for at least four centuries, both were Catholic countries able to stave off the counterreformation movement of northern Europe, and during the last half of the 16th century, both were united under a single crown (Phillip II).

Despite these impressive shared experiences, the current study shows significant policy differences between Spain and Portugal during the 16 th and 17 th centuries which produced strikingly different physical consequences in their early colonial settlements in America.

At the beginning of the 16th century, Spain and Portugal were at different stages of historical development. Portugal, having overthrown Moorish domination in 1249, had been able to consolidate the various regions politically, linguistically and culturally for two centuries before it began its program of colonial expansion. When the last vestiges of Moorish domination were overthrown in 1492, Spain was a fragmented country composed of at least three culturally distinct regions: Aragon, Castile and Andalusia. Aragon was an important water-based commercial state with Barcelona as capital; Castile was a land-based economy of the interior whose aristocratic structure and land tenure was supported by the military; Andalusia of late (1492) Christian domination, was populated largely by persons of Moslem background. When Spain undertook its program of New World expansion, it had only begun to unite itself politically, religiously, culturally under the direction of the Catholic Kings Ferdinand and Isabella.

Second, significant differences are found in flexibility in policy-making for the new colonies. Spain maintained its physical expansion through military means, offering land as payment for military services rendered by its various mercenary armies. Portugal, in turn, offered commercial concessions to Portuguese entrepreneurs who would sponsor expeditions to the Americas. These attitudes are directly reflected in the organization of colonial control mechanisms in 
the New World: Spain would opt for an organized political structure to assure economic and military dependence on and control by the Spanish Crown. Because Portugal's early political structure in America was focused on commercial activities, it was more concerned with protecting commercial endeavors and less with maintaining control of all aspects of the colonial society.

Third, differences between social makeup of populations encountered in the New World would be manifested in different political structures required for each situation. The Spanish encountered a heavy native population in most of its colonizing areas which required the creation of a hierarchical network of interdependent military, urban and religious institutions for complete domination. Newly created institutions - such as Viceroyalties, missions and presidios-assured complete domination of populations encountered in the New World. Spanish domination of the American colonies was so strongly established culturally and politically, that even today most capital cities of Spanish America remain as modern capitals of modern Latin American countries.

Portugal, which encountered very few native groups, did not need to create an elaborate social hierarchy for control of newly discovered lands. Instead, it established a series of fortified commercial outposts along the Brazilian coast, without notable linkages and hierarchies. Later these were linked to Bahia (San Salvador de Bahia), the first capital of Brazil and center for slave trading with Africa. Still later, when mining became Brazil's most important activity, the capital was shifted to Rio de Janeiro. Finally, in the 20th century, as other sectors of the Brazilian economy came into balance, the capital was shifted to its current location at Brasilia.

Fourth, policy differences are reflected in distinct differences in city form between Spanish and Portuguese colonies. Spanish towns, whether meant for Spaniards, pueblos de indios, or a mixed population, were unified into a gridded layout. It is interesting that this pattern was not common in Spain prior to the 16 th century, but was very common in the Americas from the very earliest capitals. Santo Domingo (1502), Panama Viejo (1519) and Mexico (1521) are early examples of gridded cities in Spanish America.

Portuguese colonial towns were patterned after examples in the mother country. Like Lisbon and Oporto, Portuguese colonial towns were founded in coastal areas of rugged topography which lent themselves to a bi-nodal arrangement of lower commercial ports and upper fortified towns. Many of the early Brazilian towns, such as Bahia, Olinda and Joao Pessoa still retain this distinctive pattern of two types of towns within the same city.

Finally, we have shown results of policy and physical differences in the expressions of power in the layouts of Salvador de Bahia, Brazil and Buenos Aires, Argentina. In a rigid geometry of almost square gridded streets, the Spanish colonial power structure-the Crown, the Church and the Cabildo - are focused around a single centralized open plaza of the city. In the Portuguese example of Salvador, power is expressed in relation to topography, where the lower port town becomes the focus of commercial and customs duties, while the upper fortified town contains the religious and imperial power in a complex protected by topography of the site.

Given the many cultural and geographic commonalties between the two colonizing countries, the expressions of Spanish and Portuguese domination in the Americas were distinct. The most striking differences occurred because of attitudes toward domination of the newly discovered territories and policies for control which produced different urban forms and locations of power symbols in Spanish and Portuguese colonies in the Americas.

\section{REFERENCES}

Azevedo, P. 1986. Bahia, hacia la recuperacion de un centro histórico subdesarrollado. in Francisco de Solano eds, Historia y futuro de la ciudad iberoamericana. Madrid: Consejo Superior de Investigaciones Cientificas. Universidad Internacional Menendez Pelayo.

Berry, B.; E. Conkling; D.M. Ray;1987. Economic Geography. London: Prentice-Hall.

C.E.H.O.P.U. (Centro de Estudios Históricos de Obras Públicas y Urbanismo) 1989. El sueño de un Orden: La Ciudad Hispanoamericana. Madrid. Ministerio de Obras Públicas y Urbanismo de España.

Crow, John A. 1980. The Epic of Latin America University of California Press.

Gasparini, Graziano. 1972. América, Barroco y Arquitectura. Caracas: Ernesto Armitano Editor.

Gutierrez, Ramón. 1992. Arquitectura y Urbanismo en Latinoamérica. Madrid. Ediciones Catedra. Segunda Edición.

Hardoy, Jorge E. 1978 European Urban forms in the Fifteenth to Seventeenth Centuries and their utilization in Latin America. In Schaedel, R; Hardoy, J.;Scott, K.N. eds. Urbanization in the Americas from its Beginnings to the present. The Hague:Mounton Publishers.

1991 Cartografia Urbana Colonial de América Latina. Instituto Internacional de Medio Ambiente y Desarrollo de América Latina. Buenos Aires: Grupo Editorial Latinoamericano.

Kubler, George. 1986. El urbanismo colonial iberoamericano 1600-1820. in Francisco de Solano eds, Historia y futuro de la ciudad iberoamericana. Madrid: Consejo Superior de Investigaciones Cientificas. Universidad Internacional Menendez Pelayo.

Lockhart, J. and Schwartz, S.B. 1983. Early Latin America. London: Cambridge University Press.

Marin Lou, Maria Asunción, Eduardo Múscar Benasayag 1992. Proceso de Urbanización en America del Sur. Madrid: Editorial Mapfre.

Smith, Robert C. 1955. Colonial towns of Spanish and Portuguese America. Journal of the Society of Architectural Historians, XIV, $4: 1-12$

Solano, Francisco de, ed. 1983. Estudios sobre la ciudad Iberoamericana. Madrid: Consejo Superior de Investigaciones Cientificas. Instituto Gonzalo Fernandez de Oviedo.

Soria, Jose Manuel Nieto 1991. Columbus's Spain, OAH Magazine of History. 5:18-19.

Vives, Pedro. 1986. El Ambito del Imperio en la ciudad colonial. ¿Una función desestructuradora?. in Francisco de Solano eds, Historia y futuro de la ciudadiberoamericana. Madrid: Consejo Superior de Investigaciones Científicas. Universidad Internacional Menendez Pelayo. 